\title{
Economic Essentials of Online Publishing with Associated Trends and Patterns
}

\author{
Jay Hung
}

Published online: 22 April 2010

(C) The Author(s) 2010. This article is published with open access at Springerlink.com

\begin{abstract}
This article takes a look at the common types of revenues and expenses prevalent in the online publishing world, and examines the economic trends and contrasts of upstart entities vs. larger, more established organizations. Through the use of examples and case studies, we surface information that is useful in managing for economic value.
\end{abstract}

Keywords Online publishing - Digital revenue models - Digital expenses · Technology and media - Online media - User generated content .

Crowd sourcing · CPM CPA CPC · Freemium/premium ·

Online licensing and syndication · Scripps Networks $\cdot$ Snooth $\cdot$ SetJam ·

Zynga

\section{Introduction}

In the world of online publishing, there are many types of players-from the multitude of small upstart companies, to large multi-national media conglomerates, and many others in between. While the fundamentals of the economics remains the same-revenues minus expenses equals profit - the types of revenues and expenses, and their relative contribution to the overall economic picture, will have some variances between what an upstart company may experience vs. that of a larger, more established organization.

This article takes a look at some common factors contributing to an online publisher's economic outlook, and examines the trends, similarities, and contrasts between these two types of organizations.

\footnotetext{
J. Hung $(\bowtie)$

Technologist and Director of Engineering, Scripps Networks, 301 W 53rd St \#19B,

New York, NY 10019, USA

e-mail: jay@jayhung.com
} 
Defining "Online Publishers", "Upstarts", and "Established Organizations"

For the purposes of this article, let's define an online publisher as any organization seeking to earn revenue by creating, collecting, and/or distributing content to users, typically using the World Wide Web as the primary distribution channel. Intentionally excluded are organizations whose primary business is derived from e-commerce (Amazon, eBay, and other retailers), as online commerce models are out of the scope of this article.

Let us loosely define an "upstart" (aka startup company) as a company with roughly 50 or fewer total employees (including contractors), with revenues of $\$ 10$ million or less. Likewise, we also loosely define an "established organization" as one with more than 50 employees (including contractors), with revenues of more than $\$ 10$ million.

\section{Revenues}

Many online publishers often include an advertising based component to their revenue model. It is by far the most common revenue model among online publishers, particularly those that operate destination web sites where users consume content. Table 1 shows some details of impression based ad models.

Impression based models have a direct correlation with pageviews. When pageviews go up, the ad impressions go up as well. However, not all impressions create the same value. Very specific and targeted pages tend to command higher revenue rates, and publishers who think in terms of targeted pageviews will likely drive traffic to those pages with the highest rates, to maximize monetization.

Let us take a look at some sample revenue calculations for impression based ad types. ${ }^{1}$

Based on our assumptions in Table 2, we determine the following:

$$
\begin{aligned}
& \text { Pageviews }=200,000 \text { visitors } * 5 \text { pageviews/visit }=1,000,000 \text { pageviews } \\
& \mathrm{CPM} \text { ad impressions }=1,000,000 \text { pageviews } * 2 \text { ads/page }=2,000,000 \text { ad impressions } \\
& \mathrm{CPM} \text { revenue }=2,000,000 \mathrm{ad} \text { impressions } *(\$ 6 \mathrm{CPM} / 1000 \text { impressions })=\$ 12,000 / \mathrm{mo} \\
& \mathrm{CPC} \text { revenue }=1,000,000 \text { pageviews } * 0.035 \text { click-thru } * \$ 0.20 \mathrm{CPC}=\$ 7,000 / \mathrm{mo} \\
& \mathrm{CPA} \text { revenue }=200,000 \text { unique visitors } * 0.02 \text { action completion } * \$ 2 \mathrm{CPA}=\$ 8,000 / \mathrm{mo}
\end{aligned}
$$

The projected monthly ad revenues for our sample online publisher are shown in Table 3 .

\footnotetext{
1 Calculations provided for example purposes only. Real world scenarios depend on other factors, including limited ads per rate, multiple rates, etc.
} 
Table 1 Impression based ad revenues

\begin{tabular}{|c|c|c|}
\hline & Description & Sample companies employing model \\
\hline CPM & $\begin{array}{l}\text { - Cost-per-thousand impressions } \\
\text { - Many ad networks }\end{array}$ & $\begin{array}{l}\text { Yahoo!, Food Network, All Recipes, Evernote, } \\
\text { Tweetie }\end{array}$ \\
\hline $\mathrm{CPC}$ & $\begin{array}{l}\text { - Cost-per-click (aka pay-per-click) } \\
\text { - Auction format; highest bidder determines } \\
\text { rates }\end{array}$ & $\begin{array}{l}\text { Google.com }{ }^{\mathrm{a}} \text {, About.com, ClipArtPal.com, and } \\
\text { generally any site that employs Google AdSense }\end{array}$ \\
\hline $\mathrm{CPA}$ & $\begin{array}{l}\text { - Cost-per-action (publisher paid when users } \\
\text { complete an action or accepts an offer) }\end{array}$ & $\begin{array}{l}\text { Kayak.com, Snooth.com, PokerAffiliateBible.com, } \\
\text { SetJam.com }\end{array}$ \\
\hline
\end{tabular}

${ }^{a}$ In the case of Google itself, the AdSense product is the ad network, and Google.com is the "publishing product" (distribution) that serves CPC ads

Table 2 Advertisement assumptions for sample online publisher

\begin{tabular}{lc}
\hline Assumptions & Value $^{\mathrm{a}}$ \\
\hline Monthly unique visitors & 200,000 \\
Pageviews per visit (average) & 5 \\
$\#$ of CPM ads per page & 2 \\
$\#$ of CPC ads per page & 2 \\
CPM revenue rate (average) & $\$ 6$ \\
CPC revenue rate (average) & $\$ 0.20$ \\
CPC click-thru penetration (average) & $3.5 \%$ \\
CPA revenue rate (average) & $\$ 2$ \\
CPA penetration (average) & $2 \%$ \\
\hline
\end{tabular}

${ }^{a}$ These values will vary depending on your particular site and category area. You may substitute your own actual numbers, if available

b Penetration rate for how often an ad is actually clicked based on how often it is displayed

c Penetration rate for how many of our total monthly visitors actually completes an action/transaction that results in a CPA commission

Table 3 Projected monthly revenues for sample online publisher

\begin{tabular}{lr}
\hline Type of revenue & Monthly $\$$ \\
\hline CPM revenues & $\$ 12,000$ \\
CPC revenues & $\$ 7,000$ \\
CPA revenues & $\$ 8,000$ \\
Total & $\$ 27,000$ \\
\hline
\end{tabular}

Table 4 examines some other common revenue models including sponsorships, affiliate commissions, pay-per-use, freemium/premium, subscriptions, and licensing/syndication. 
Table 4 Other common revenue models

\begin{tabular}{|c|c|c|}
\hline & Description & Sample companies employing model \\
\hline Sponsorships & $\begin{array}{l}\text { - Advertisers pay fee to associate with a } \\
\text { specific event, promotion, or other } \\
\text { campaign } \\
\text { - Typically sold as a fixed fee campaign } \\
\text { - Often combined with a CPM based } \\
\text { component with a guarantee on the } \\
\text { number of impressions to deliver }\end{array}$ & $\begin{array}{l}\text { Potential sponsors include American } \\
\text { Express, Home Depot, Kraft Foods, } \\
\text { Kohl's }\end{array}$ \\
\hline Affiliates & $\begin{array}{l}\text { - Essentially "customer referral/marketing" } \\
\text { - Popular with merchants paying } \\
\text { commissions for transactions generated } \\
\text { by an affiliate }\end{array}$ & $\begin{array}{l}\text { Affiliate publishers include Shopzilla, } \\
\text { Snooth.com, BookReporter.com, } \\
\text { ScientificAmerican.com }\end{array}$ \\
\hline Pay-Per-Use & $\begin{array}{l}\text { Pay for each use (aka pay-per-item, } \\
\text { pay-per-download) }\end{array}$ & $\begin{array}{l}\text { Publishers that sell assets via Apple's } \\
\text { iTunes store, Amazon Web Services, } \\
\text { Amazon Kindle Bookstore }\end{array}$ \\
\hline $\begin{array}{r}\text { Freemium/ } \\
\text { Premium }\end{array}$ & $\begin{array}{l}\text { - Free basic version of product/service } \\
\text { (sometimes subsidized by ads) } \\
\text { - Optional premium versions offering new } \\
\text { and enhanced features } \\
\text { - Very popular among game publishers a and } \\
\text { utility applications }{ }^{\text {b }} \\
\text { - iPhone's introduction of "in-app" } \\
\text { purchases has catalyzed the growth of } \\
\text { freemium apps }\end{array}$ & $\begin{array}{l}\text { Yahoo! Mail, LinkedIn, Pandora, Flickr, } \\
\text { Evernote, YouMail, and many online/ } \\
\text { mobile games }\end{array}$ \\
\hline Subscriptions & $\begin{array}{l}\text { - Based on a subscription price (recurring } \\
\text { fee) } \\
\text { - May have "trial" product (no freemium } \\
\text { version) }\end{array}$ & Netflix, Wall Street Journal \\
\hline $\begin{array}{l}\text { Licensing \& } \\
\text { Syndication }\end{array}$ & $\begin{array}{l}\text { - Monetized by collecting licensing fees } \\
\text { - May be fixed fees, per seats, or other } \\
\text { variations }\end{array}$ & $\begin{array}{l}\text { Mayo Clinic, Healthwise, Twitter, } \\
\text { iStockPhoto, Food Network }\end{array}$ \\
\hline
\end{tabular}

\footnotetext{
a This Sep 2009 survey reports that over half (58\%) of gamers have made purchases in freemium games: http://www.virtualgoodsnews.com/2009/09/over-half-of-gamers-purchasing-in-freemium-games.html

b Note taking application Evernote boasts 2.7 million total subscribers, with over 50,000 premium subscribers: http://mobile.venturebeat.com/2010/03/26/freemium-summit-evernote-shares-the-insider-secrets-of-freeapps/
}

\section{Expenses}

As with revenues, there are many different types of expenses. For purposes of this article, we have grouped the various expenses into various buckets as shown in Table 5.

Expenses vary among all type of publishers, upstarts as well as established, and will be dependent on how efficiently a business is run. Let's cover more about this in the next section. 
Table 5 Common expense buckets for online publishers

\begin{tabular}{|c|c|c|}
\hline & Description & Sample expenses \\
\hline $\begin{array}{l}\text { Content \& } \\
\text { production }\end{array}$ & $\begin{array}{l}\text { - Expenses associated with the creating, } \\
\text { producing, purchasing, and acquiring of } \\
\text { content } \\
\text { - Costs will vary depending on type of } \\
\text { content (flat vs. video, etc) and type of } \\
\text { business (tv shows vs. social/user- } \\
\text { generated content) } \\
\text { - Crowd sourcing a is a relatively new and } \\
\text { sometimes viable option (google "Netflix } \\
\text { Prize"b) }\end{array}$ & $\begin{array}{l}\text { Designers, editors, project managers and } \\
\text { coordinators, site directors, producers, } \\
\text { content licensing fees, research and } \\
\text { analytics, production costs }\end{array}$ \\
\hline $\begin{array}{l}\text { Software } \\
\text { development }\end{array}$ & $\begin{array}{l}\text { - Mostly labor and some software license } \\
\text { costs associated with building and } \\
\text { maintaining the software systems for } \\
\text { managing, publishing, and distributing } \\
\text { content } \\
\text { - Can be enterprise content management, to } \\
\text { digital asset management, to custom } \\
\text { programming applications }\end{array}$ & $\begin{array}{l}\text { Software engineers, quality assurance } \\
\text { analysts, project/product managers, } \\
\text { development tools, software licenses }\end{array}$ \\
\hline Infrastructure & $\begin{array}{l}\text { - Costs of hardware, software, operating } \\
\text { systems, hosting and bandwidth for the } \\
\text { storage and distribution of content } \\
\text { - May include enterprise IT operations, } \\
\text { desktop support, test environments, } \\
\text { Internet connection fees }\end{array}$ & $\begin{array}{l}\text { Hardware (servers, routers), bandwidth and } \\
\text { hosting, software licenses, operations and } \\
\text { network engineers }\end{array}$ \\
\hline $\begin{array}{l}\text { Traffic } \\
\text { acquisition }\end{array}$ & $\begin{array}{l}\text { - Aka user acquisition costs } \\
\text { - Costs associated with acquiring unique } \\
\text { users, increasing pageviews, and } \\
\text { promoting site activity } \\
\text { - SEO = improving organic (non-paid) } \\
\text { traffic } \\
\text { - SEM = paying for sponsored traffic } \\
\text { - Social = marketing via social networks } \\
\text { (Facebook, MySpace, Twitter, YouTube, } \\
\text { etc) } \\
\text { - Goal is to be viral! }\end{array}$ & $\begin{array}{l}\text { Traditional marketing (print, online } \\
\text { banners, etc), SEO, SEM, social media } \\
\text { marketing }\end{array}$ \\
\hline $\begin{array}{l}\text { Sales \& } \\
\text { business } \\
\text { development }\end{array}$ & $\begin{array}{l}\text { - Cost associated with ad sales, } \\
\text { partnerships, and business development }\end{array}$ & $\begin{array}{l}\text { Sales analysts, business development } \\
\text { analysts }\end{array}$ \\
\hline $\begin{array}{l}\text { Other } \\
\text { operational }\end{array}$ & - Bucket for everything else & $\begin{array}{l}\text { IT operations, desktop support, legal, rent, } \\
\text { facilities, other misc costs }\end{array}$ \\
\hline
\end{tabular}

${ }^{a}$ For more info on crowdsourcing, see Wikipedia: http://en.wikipedia.org/wiki/Crowdsourcing

b Popular 2006 contest where Netflix offered \$1 million USD to the contestant that improves their movie recommendations by $10 \%$. This contest spurned the participation of many, many smart people-including the world's foremost experts in statistics and engineering - much more brainpower than Netflix could've paid, in salaries, with the same \$1 million: http://en.wikipedia.org/wiki/Netflix_Prize

c From Wikipedia http://en.wikipedia.org/wiki/Social_media_marketing 


\section{Upstarts vs. Established Organizations: Examples and Case Studies}

This section takes a closer look at the revenues and expenses identified above, and examines the varying dynamics between the upstarts and the established organizations. It is important to remember that the information below is intended to portray trends and patterns in execution, and are not meant to be recommendations of how to operate a business.

\section{Advertisement Revenue}

Almost all publishers that receive any meaningful level of traffic will have some sort of advertisement monetization based on unique users and pageviews. The more unique users (and pageviews) that your site has, the more available ad inventory that you have to sell —and the higher a rate you will be able to command. The category of your content will also affect what kind of rate you can command, as well as which types of advertisers you will be able to attract.

With limited capital that runs out quickly, one of biggest hurdles for upstarts is getting enough users and traffic to start the revenue engine. Larger, more established publishers have longer runways and can afford a longer time in building traffic and a user base.

Upstart publishers, especially in the early stages, may not have a direct sales force in place to sell their inventory. Often times, it behooves the upstart to join an ad network, who will then sell the inventory but take a percentage of the proceeds, resulting in lower rates and profits. Any inventory that is not sold is usually subject to run-of-house ads, which are ads with extremely low rates, generating little or no income.

Established publishers often have their own direct sales force, resulting in higher rates and better sell-through of inventory. Often, large publishers are able to "addon" their online advertisement sales as part of a larger buy. For instance, an advertiser such as Kraft may buy an on-air ad campaign on the Food Network's cable channel that also includes an online campaign on the web site FoodNetwork.com.

Sponsorships usually require a sales force to sell, and thus tend to be more prevalent among established companies. Sponsorships are often sold as a fixed sum based on a guaranteed delivery of total impressions to pages "bought" by the sponsor. Publishers then program and promote the site to optimize the delivery of these impressions. Any shortage in the actual delivered impression count may result in a partial refund, or a discount on future campaigns.

\section{Publishers Commonly Employ a Mixture of Revenue Types}

Many publishers, large as well as small, commonly employ multiple types of advertisement revenue in their sites. If you are a new publisher, I encourage you to try a combination of different advertisement streams, to find the balance that works best for you, and optimizes your revenue based on the traffic patterns your site generates. 


\title{
Case Study: Snooth.com
}

Snooth.com, the world's largest wine review site but relatively small upstart with 10 employees, leverages both the CPM as well as CPA model, along with sponsorship campaigns. They began as a lead-generation business, earning revenues from the CPA model. As they've grown their audience and their content, they've evolved into a media business, now earning a huge majority of their revenues from CPM advertising. With that evolution, Snooth has hired and grown a direct sales force, and now boasts sponsors the likes of American Express, Visa, and Sony.

\section{Case Study: Scripps Networks}

Scripps Networks (NYSE:SNI), a large publisher with over 2000 + employees, employs the CPM, CPC, CPA, sponsorships, pay-per-use via iTunes downloads, freemium/premium, and licensing/syndication models across its portfolio of online sites, including FoodNetwork.com (the world's largest food and recipe site), Recipezaar.com (the world's largest user generated recipe database), HGTV.com, and others. Scripps Networks has their own direct sales staff, and often sells bundled packages to advertisers that include both on-air as well as online ad inventories.

\section{Common Conundrum: 80/20 Rule of Sponsored Campaigns ${ }^{2}$}

Worth mentioning here is a common conundrum that I have seen with many of the sponsorship campaigns I've been involved with in the past decade. It revolves around spending $80 \%$ of the efforts on pages garnering $20 \%$ of the ROI. Let's take a look at the following case study, which illustrates this:

\section{Fictitious Case Study: A Sponsored Campaign on Yahoo! Health ${ }^{3}$}

\begin{abstract}
A birth control drug company ("sponsor") buys a campaign on Yahoo! Health ("publisher"). Their intent is to reach the greatest audience of users that may be potential customers of their birth control pills, and their campaign includes buying out most of the articles that relate with pregnancy or planned parenthood. The article pages already exist, and may take some minor dressing up to better showcase the sponsor's logo and advertisement. A new landing page, and potentially some sub-landing pages, are often created as a "doorway" to the sponsored campaign, including links to the various articles that are a part of the campaign. Often, a generous amount of effort is put into designing and building these landing pages, yet they usually generate a lower number of pageviews, which is reduced value to the sponsor. ${ }^{4}$ In addition,
\end{abstract}

\footnotetext{
2 The $80 / 20$ ratio is used for emphasis purposes only and may not reflect actual ratios. The point is that more effort is sometimes spent on areas with low ROI.

3 The use of the Yahoo! Health web site is purely for example purposes only. Any similarities between this example and an actual campaign are purely coincidental and not intended.

4 Many landing pages simply surface content and provide links to targeted detail pages (articles, recipes, etc) and these days SEO drives many users to these targeted pages sideways via search engine results, and not always via the front landing pages.
} 
these landing pages, because they are not as targeted as a specific content detail page, command a much less CPM rate, and thus less value to the publisher. ${ }^{5}$ This means the pages with the highest production costs generate the least return in value, for both sponsor as well as publisher. Why then, do campaigns repeatedly follow this same pattern?

Here's my take on the situation. The sponsor typically has a project manager, or other point person, in charge of their campaign. This individual reports to his or her boss on the progress as well as successful launch of the campaign. A catchy, eye-popping "front landing page" simply makes for a much more impressive presentation and talking point, even if it produces less value for the sponsor in terms of results. In addition, any effort that is expended in driving traffic to the landing page is essentially driving traffic away from the highvalue content pages with the higher ad rates.

In short, this dilemma of spending the most effort on the pages with the lesser values ultimately produces lower results for the sponsor, and generates less revenue for the publisher.

\section{Advertising and User-Generated Content}

Many large advertisers are hesitant to advertise on pages with user-generated content, for the lack of control and predictability in what users may upload or say. This creates a risk that their ad-and effectively their brand-will be displayed on and associated with a web page containing "inappropriate" content.

Fictitious Case Study: Hoken Pharmaceuticals and Benefide Health ${ }^{6}$

Hoken Pharmaceuticals produces a new drug for erectile dysfunction. Hoken would like to purchase an ad campaign on Benefide Health's website that includes 5 million impressions across their planned parenting, birth control, relationships, and sexual health \& STD article pages. Benefide Health wants to up the buy by including the pageviews for their user discussion forums, as well as the comments and reviews sections, at half the CPM rate, as these sections generate an additional half a million impressions per month.

Despite the highly reduced rate, Hoken opts not to buy these pageviews, as there is little control over what information a user may post, and little policing possible. You can imagine the type of comments that may surface with a topic like erectile dysfunction, and online users are highly resistant to being censored on web sites that solicit their input (comments, reviews, as well as discussion forums). Doing so usually creates a backlash of negative remarks and "post/flame wars".

\footnotetext{
5 Sponsors often also buy out all of the ad impressions on these pages, so the CPM rate may be moot as there will be no other advertisers.

6 These are fictitious company names for the purposes of this article, and any resemblance to real companies with the same names is purely coincidental and unintentional.
} 
Nevertheless, advertisers are increasingly recognizing the power of usergenerated content with the relevant explosion of social media, and expect more to be experimenting in the user-generated arena moving forward.

\section{Examples of the Affiliate Model at Work}

\section{Case Study: SetJam.com}

SetJam is a new, small upstart helping to connect people to their favorite TV shoes and movies. Using their highly indexed search engine, users can search out every TV show and movie, and SetJam will find and return all of the options for viewing that show or movie. If a user selects a pay option (rent or buy), SetJam makes an affiliate commission upon completion of the transaction. SetJam also provides social features allowing users to share their favorite shows and movies with their friends, helping to leverage social media for marketing and distribution. In addition to CPA, SetJam earns revenue by monetizing their site traffic with CPM ads. The more users that use SetJam, the more CPA transactions that are completed, the more CPM impressions that are served, and the more revenue that SetJam will make. SetJam does not have a large marketing budget, so a lot of their strategy is based on SEOspecifically intended to create pages that will be indexed and appear in Google's search results.

\section{Case Study: Zynga.com}

Zynga is another example of an online publisher leveraging the affiliate model that has enjoyed great success and grown explosively fast. While Zynga is a private company and does not share financial numbers, speculation has them earning over \$200 million in revenues in $2009 .^{7}$ Zynga is a publisher of social games-games that are played over social networks and often between friends. These games are typically free to play, but provides users the ability to "level up" by purchasing "virtual credits" with real money that can then be used in the game to get ahead. Users who do not wish to make these purchases are alternately presented with a number of "offers" from sponsors, and if a user signs up for one of these offers, they will then receive similar credits that can used in the game. And Zynga is paid a fee for each offer sign-up. Although Zynga buys advertisements on the social network sites to generate visibility and recruit new gamers, a big part of their marketing strategy is baked into the game itself: as users perform activities in the games, messages and requests are sent out to friends on their social network news feeds requesting their help or simply promoting the game, generating more click-thrus and new player sign-ups. This type of marketing, once created, can become viral but is more or less free. It plays a huge factor in maintaining a level of game activity that is highly profitable.

\footnotetext{
${ }_{7}$ Figures taken from http://www.insidesocialgames.com/2009/11/23/the-latest-stats-on-zynga-new-trafficrevenue-and-a-1-billion-valuation/.
} 


\section{Freemium/Premium Revenues}

In my opinion, the freemium/premium model tends to work very similarly between upstarts vs. established publishers. What seems to be a contrast however is that while most successful upstarts employing a freemium model commonly to have a large or majority percentage of their revenues from the premiums, many established publishers that have a freemium product tend to make a much smaller percentage of their overall revenues from freemium.

\section{Licensing and Syndication Revenues}

A large publisher, especially one that creates original content (HGTV, HBO, MTV, etc) can usually generate additional revenues by licensing their content via syndication channels. These channels may be anything, from international markets (ie US shows syndicated to UK audiences) to alternate distribution networks (old movies and shows syndicated to Turner Network Television, etc), and a fee is usually received up front.

Smaller publishers may also syndicate or license their content. Snooth.com, the world's largest database of wine reviews, licenses their extensive database of wine and food pairings to various recipe sites around the web, including Epicurious.com and MyRecipes.com.

\section{Content and Production Costs}

Established companies of course can afford a much larger budget for content and production costs. Depending on the type of company and the type of content, costs can be quite high.

Smaller upstarts tend to be more frugal here, as with less capital to employ, they generally can't afford large content budgets. As a result, many have found ways to leverage user-generated content, and more recently, crowd sourced content.

Established companies are also getting into the fray with both user-generated content as well as crowd sourced content (the latter to a lesser extent). However, established companies tend to be much more conservative, and often choose to move slower in these areas. They generally have less of an understanding of how best to leverage user-generated content, even though many organizations having "social media experts" on staff. Traditionally, many larger companies consider "comments, ratings, reviews, and discussion forums" the extent of user-generated content, but in recent years more have began to incorporate enhanced features such as user submitted articles, photos, graphics, and more.

Case Study: HGTV.com (an established publisher)

HGTV.com showcases articles, photo galleries, how-to's, videos, and other programming content for connecting users with their passion for their homes. There are significant production costs for their television shows (recorded against the on-air division). In the online division, the content and production 
costs include personnel such as site directors, editorial staff, designers, video and image processing staff, photo and font licensing fees, and more.

HGTV.com is one of the more forward-thinking larger publishers in terms of user-generated content. They have a popular user-generated content product, "Rate My Space", which allows users to upload photos of their various rooms and allow other users to rate and comment on them. While there is engineering cost in creating the product, thereafter the content costs are zero as users submit their images for free. Interesting enough, the success of the online product spawned a television show of the same name, which bears the same production costs as any other show.

Case Study: SetJam.com (an upstart publisher)

We continue to examine SetJam here, as they are ideal in illustrating a publisher with very low content and production costs. SetJam's product is a utility application — an online database, directory, and search engine-for tv shows and movies.

They heavily utilize public APIs (application programming interfaces) of other online services to retrieve their data. Each show or movie receives its own "detail landing page", which is an indexable page in Google and other search engines. When optimized effectively, SetJam's pages will show up in search results when users search for shows and movies, enabling a potential stream of inbound traffic to their site. They do not pay for the content, or if anything, pay a relatively small fee for access to the APIs.

\section{Software Development and Infrastructure Costs}

Upstarts tend to favor open-source software and platforms, as these small organizations do not have the budgets to spend on enterprise software. The types of engineers that are attracted to upstarts also tend to be more in tune with the open source communities, which they would have to be.

Established organizations, especially large corporations, on the other hand, tend to favor enterprise software with extensive (and expensive) support contracts. These organizations want reassurance that if anything goes wrong, they will be able to call someone on the phone that can help them with a solution. A large organization that wishes to use open source may not always do so very well. This would depend on the types of engineers that work for these organizations, as they will need to know how to utilize the open source communities to research and find solutions to problems.

Many companies also have opted to offload portions of their development offshore, to places such as India and China, and more recently to South America as well as Canada. Ask several technology managers and you will likely receive different opinions of offshore development. The gains you may get from the reduced rates for offshore developers may be offset by the additional challenges you may experience in managing across geographical boundaries and time zones. Sometimes, you may also pay a cost in the quality of talent you receive as well. 
Newer regions to the offshore services industry such as South America and Canada can now offer similarly reduced rates with a more favorable time zone to work.

If you are truly interested in offshoring development, you may be interested in a variation-working with an onshore vendor whose developers work offshore. This is one that I have had great success with. The points of contact for the vendor, usually project managers or company owners, are located on shore, and meetings are conducted normally within the same time zones, and within regular business hours. Seldom do we communicate with actual developers-instead, the vendor will communicate tasks and product requirements to their developers offshore, and new development is typically done during our nighttimes. New software updates are delivered the following mornings. The rates are reasonable, and the code and product quality are good.

Whatever you decide to do, make sure you evaluate it on a total cost basis, and not just on a per hourly rate basis. This ensures that you are including your overhead of managing the offshore team as well as the cost of the team itself.

\section{Traffic Acquisition Costs}

So now that you are a publisher with great content, have a product/website built to showcase your content, and have the right infrastructure in place in terms of delivering the content, how do you begin distribution of this content to users? How do you enable your users to find you? How will you drive traffic to your site?

\section{SEO}

SEO is a huge factor in today's Web in driving traffic. It has evened the playing field between small, upstart companies with little to zero marketing budget vs. the larger, more established counterparts. with the big marketing budgets simply by doing SEO successfully. In today's highly competitive online landscape, it becomes increasingly critical to have your SEO strategy and technique baked into your product's DNA. In order to succeed, it cannot be an afterthought, an extra "topping" to be "sprinkled in" afterwards.

Smaller upstarts will almost unanimously employ only SEO in their traffic acquisition strategy. Much of the driving force behind this is cost. Someone who either has a good grasp of the underlying fundamentals of SEO (or can learn quickly), can ultimately do an effective job. And many upstarts, rather than hire an external SEO specialist or consultant, will choose to develop this expertise in-house, typically adding this role to an existing employee's responsibilities so as not to incur any additional costs.

In comparison, many larger and more established organizations choose to hire for the role-often an expensive, external SEO consultant/expert, and sometimes a new direct hire whose sole responsibility is to manage SEO initiatives. In addition, because they can usually afford some sort of budget for SEM, it is rather common to see a combination of both SEO and SEM employed by larger and more established companies. Hiring an external consultant also has long-term drawbacks, as the company will lose whatever SEO effectiveness they have when the consultant 
leaves after finishing his or her projects. And with continuously increasing attacks in SEO from competitors, no organization, big or small, can afford not to have this expertise internally.

\section{Common Oversight: On-page SEO vs. Off-page SEO}

A frequent mistake/oversight I see many organizations make, big or small, is to focus their attention and investment predominantly on "on-page SEO" and not putting enough effort, if at all, to "off-page SEO".

On-page SEO is the practice of writing, coding, and structuring the information on your page to be optimal for your particular subject area and related keywords. This includes optimization of your page title, using the right page headers with the correct keywords, getting the most important information up closer to the top of the page, improving the structure of urls with the use of friendly words, using appropriate link text, and so forth. But, on-page SEO contributes to arguably only a $1 / 3$ to $1 / 2$ of a site's ranking score-another $1 / 3$ to $1 / 2$ is contributed to by off-page SEO.

Off-page SEO is the practice of improving your site's ranking by efforts that happen off of your website's pages. Many of these efforts revolve around building your link popularity, or in other words, increasing the number of websites that will link to yours. There is excellent indication to support that the more sites you have linking to yours, and the higher the ranking of the sites linking to yours, the more likely your site's ranking will increase.

A site's overall SEO effectiveness increases on a logarithmic scale-the more effective your site becomes with SEO, the harder it is to increase that effectiveness even further. Apply this to both types of SEO: once you've improved your on-page SEO close to the top, it becomes increasingly more difficult to have even better onpage SEO results. Rather than spending more time and money into on-page SEO after reaching a certain SEO performance level, an organization should allocate more resources into improving their off-page SEO.

\section{Case Study: FoodNetwork.com vs AllRecipes.com}

FoodNetwork.com has long been the \#1 food site on the Internet, in terms of monthly unique users and monthly pageviews. The success and reach of their television shows are phenomenal in creating brand recognition and customer retention, in turn helping to drive a significant number of viewers online to their website.

AllRecipes.com, on the other hand, has an online presence only, and not too long ago, was an upstart with a relatively small but growing online audience. What AllRecipes.com did was focus on their SEO strategy, and they did a tremendous job of it (both on-page as well as off-page). And while unable to match the longevity and popularity of FoodNetwork.com, slowly, month after month, AllRecipes.com grew their reach and online presence, and now is the \#2 food site on the Internet. ${ }^{8}$

\footnotetext{
${ }^{8}$ Rankings are based on monthly traffic metrics from comScore Media Metrix.
} 


\section{SEM}

Most upstarts do not have the budget to support any SEM efforts, but established organizations may choose to augment their marketing and traffic acquisition with SEM campaigns.

The cost of SEM includes an additional budget where certain keywords may be purchased, so that a web site's entry is displayed as part of the sponsor results (paid listings) of a search results pages. These fees can be based on a CPC (cost per click) — meaning the advertiser/buyer pays for each click that is made on their paid listing. The rate/fee paid for each click varies for each keyword, and is set based on the highest bidder for that particular keyword. As you can imagine, very popular keywords can get expensive very quickly. ${ }^{9}$

Alternatively, SEM fees can be based on a CPM model (cost per thousand impression)-meaning a fee is paid based on the number of impressions shown (usually as a guaranteed impression count). To help control costs, you can usually specify a cap either in the number of impressions or dollar amount spent.

\section{Social Media}

In a large organization, it will not be uncommon to see separate roles and bodies responsible for social media marketing. Sometimes these may also be external consultants/experts. It seems these days that everyone is a "social media expert", and many of these experts come with very expensive rates.

Contrast this to a small upstart organization, where the above roles of SEO/SEM/ Social likely are rolled into a single person, who also has additional responsibilities.

Like SEO, understanding "social" does not take a rocket scientist, or a "social media university" - it simply takes persistence in understanding how social networks work, and how to leverage the various tools that are available (ie Facebook, LinkedIn, Twitter, etc).

All of these-SEO, SEM, Social-ultimately affects your total traffic acquisition costs. Taking the total budget spent on traffic acquisition, and dividing by the number of unique users that your site reaches, will give you the cost that you pay for each unique user to your site. Adjusting the balance of where you spend more investment on, relative to the results that you are able to achieve, will allow you to manage your costs effectively.

\section{The Viral Phenomena}

In today's world, the best products are viral—where users will share and promote the product among their social networks with such rapidness that they achieve mass distribution in a very short amount of time, and very cost effectively. For almost all products that fit this category and are viral, the SEO and social distribution is built directly into the product. The point I am illustrating here is that companies no longer

\footnotetext{
9 See http://www.xedant.com/researches/top_500_adsense_keywords.php for a list of top 500 most expensive keywords for Google AdSense.
} 


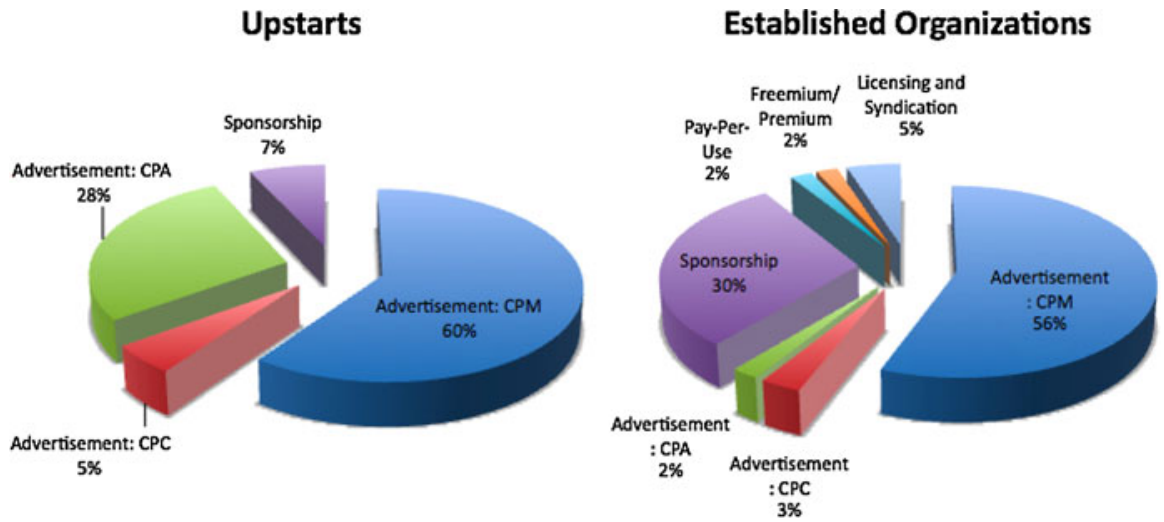

Fig. 1 Revenue breakdowns

\section{Upstarts}

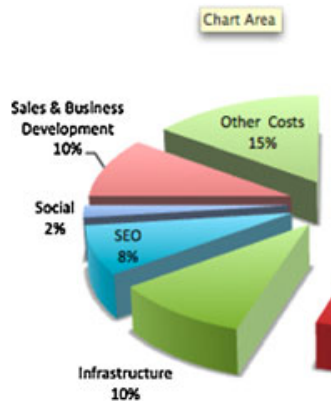

\section{Established Organizations}

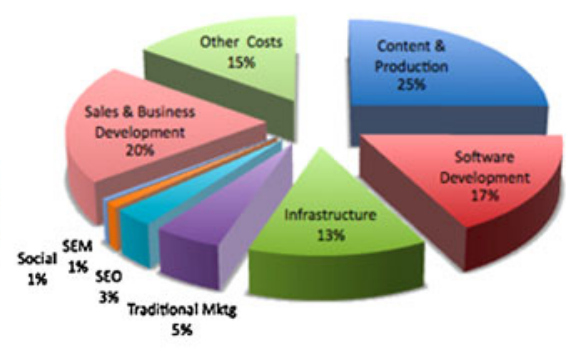

Fig. 2 Expense breakdowns

need to spend a lot of money to achieve critical mass if they are able to achieve a viral effect.

\section{Comparisons}

Here are some sample charts portraying the percentage breakdowns for various revenue and expense items of upstarts vs. established organizations. It is provided for example purposes only, as even among the handful of companies polled for this article, there were wide variances in the percentages. It is in no way intended to be a recommendation of how to operate your business (Figs. 1, 2). ${ }^{10}$

This next table summarizes some of the trends that we've identified between upstarts and established organizations (Table 6).

\footnotetext{
${ }_{10}$ Percentages based on conversations with a handful of publishers operating destination-based content web sites.
} 
Table 6 Trends comparison

\begin{tabular}{|c|c|c|}
\hline & Upstarts & Established organizations \\
\hline \multirow{4}{*}{$\begin{array}{l}\text { Organizational } \\
\text { dynamics }\end{array}$} & Less capital, fewer resources & More capital, more resources \\
\hline & $\begin{array}{l}\text { Hires generalists (less headcount; wears } \\
\text { Multiple hats across functions) }\end{array}$ & $\begin{array}{l}\text { Hires specialists (more headcount } \\
\text { performing specialized functions) }\end{array}$ \\
\hline & $\begin{array}{l}\text { Focused execution on } 1 \text { or } 2 \text { key } \\
\text { initiatives }\end{array}$ & $\begin{array}{l}\text { Multiple, parallel projects supported by } \\
\text { matrix teams }\end{array}$ \\
\hline & Agile and nimble; fast execution & $\begin{array}{l}\text { More overhead from additional layers of } \\
\text { management and approval chains }\end{array}$ \\
\hline \multirow[t]{3}{*}{ Revenue trends } & $\begin{array}{l}\text { Commonly employ ad networks; less } \\
\text { direct sales }\end{array}$ & $\begin{array}{l}\text { Primarily sells via direct salesforce; higher } \\
\text { rates }\end{array}$ \\
\hline & Impression based models more common & $\begin{array}{l}\text { More ability to sell licensing and } \\
\text { syndication deals }\end{array}$ \\
\hline & $\begin{array}{l}\text { One of the most important hurdles is to } \\
\text { build enough traffic fast enough to } \\
\text { generate initial revenues }\end{array}$ & $\begin{array}{l}\text { Typically does not need to drive revenues } \\
\text { immediately, and can experiment more or } \\
\text { afford more mistakes }\end{array}$ \\
\hline \multirow[t]{6}{*}{ Expense trends } & Much leaner and more capital efficient & $\begin{array}{l}\text { More overhead and higher operating } \\
\text { expenses }\end{array}$ \\
\hline & Engineering often bulk of costs & $\begin{array}{l}\text { Engineering is a lesser percentage of } \\
\text { overall expenses }\end{array}$ \\
\hline & Infrastructure costs generally lower & Higher infrastructure costs \\
\hline & Less content costs & Higher content costs \\
\hline & $\begin{array}{l}\text { Open source software commonly reduces } \\
\text { infrastructure costs }\end{array}$ & $\begin{array}{l}\text { Favors enterprise software with expensive } \\
\text { support contracts }\end{array}$ \\
\hline & $\begin{array}{l}\text { Salaries can be below market; may be } \\
\text { offset by equity (stock options) }\end{array}$ & Competitive market salaries \\
\hline \multirow{2}{*}{$\begin{array}{l}\text { Content \& } \\
\text { production } \\
\text { trends }\end{array}$} & Smaller content budget & Higher content budget \\
\hline & More user-generated and social content & More original content \\
\hline \multirow{4}{*}{$\begin{array}{l}\text { Traffic \& } \\
\text { distribution } \\
\text { trends }\end{array}$} & $\begin{array}{l}\text { Primarily focused on SEO and social } \\
\text { (often baked into product design) }\end{array}$ & $\begin{array}{l}\text { SEO and social usually added in after the } \\
\text { fact (after a product's been built) }\end{array}$ \\
\hline & Seldom any SEM & $\begin{array}{l}\text { More likely to include SEM as part of } \\
\text { strategy }\end{array}$ \\
\hline & Focus on increasing pageviews per user & Focus on increasing pageviews per user \\
\hline & $\begin{array}{l}\text { Frequently marketed online only, and with } \\
\text { little to zero advertising buys }\end{array}$ & $\begin{array}{l}\text { Frequently augmented with marketing } \\
\text { efforts including offline and } \\
\text { advertisement buys }\end{array}$ \\
\hline
\end{tabular}

\section{Conclusion}

An understanding of the fundamentals of the types of revenues and expenses faced in the online publishing world, coupled with awareness of various trends and patterns experienced within both upstart and established environments, will enable you to better manage the economics of your business.

Publishers that are able to leverage multiple revenue types will be able to better weather the frequently changing dynamics of the online world and evolve their business. Impression based ad models continue to be the more dominant model 
among publishers, contributing to a greater percentage of the revenues for both upstarts as well as established organizations. As such, it drives most publishers to focus on maximizing pageviews per user as a means of increasing their traffic, and thus their revenues. And by controlling costs and keeping burn rates low, both upstart as well as established publishers alike can strategize for another important metric-maximizing revenue per user.

Open Access This article is distributed under the terms of the Creative Commons Attribution Noncommercial License which permits any noncommercial use, distribution, and reproduction in any medium, provided the original author(s) and source are credited. 